\title{
BIOLOGICAL ASPECTS OF THE TRUE SPIDER Latrodectus geometricus KOCH 1841(ARANEAE: CHECKED THERIDIIDAE) FEEDING ON DIFFERENT PREY UNDER LABORATORY CONDITIONS \\ Mohafez, M.A.M \\ Faculty of Agriculture, Al-Azhar University, Cairo, Egypt
}

\begin{abstract}
This study was conducted to rear the spider Latrodectus geometricus Koch, 1841 (Theridiidae) when fed on different prey under laboratory conditions. The biological aspects including, 1-mating, 2-oviposition, 3development, 4-adult longevity 5-lifecycle, 6-moulting, and 7-predation efficiency were carried out. Male and female pass through four and eight immature stages (spiderlings) respectively before reaching adult stage with the life cycle averaged $91.15 \& 198.57$ days respectively at $25{ }^{\circ} \mathrm{C}$. and relative humidity of $70-80 \%$. Obtained data also showed that the first and second spiderling consumed the largest number of red spider (Tetranychus urticae), both to sexes spiders, while the third and fourth spiderling fed on the Drosophila melanogaster. From fifth spiderlings two adult; the individuals fed on the different stage from larvae Spodopetra lettrolaris for males and females. However, the longevity periods of the spider lasted 25.4. and 171 39.71 days for male and female.
\end{abstract}

\section{INTRODUCTION}

The role spiders play in the natural biological control of agricultural pests has received limited investigation (Huffaker and Messenger, 1976). The four important roles of spiders in the agroecosystem were outlined by Whitcomb (1973) and include :( a) spiders prey on destructive insects ;( b) spiders serve as food for other predators ; $(\mathrm{c})$ since spiders tend to be general feeders, they are enemies of beneficial insects ; and (d) spiders compete with insect predators for prey . Dondale (1958) and Putman (1967) reported that; in orchards, members of the Salticidae, Thomisidae and Theridiidae were the most numerous spider species. Prey records are necessary in analyzing the importance of spiders as predators in an agroecosystem. Previous prey investigations have indicated only that spider .Prey investigations under natural conditions (Robinson and Robinson 1970) under laboratory conditions (Eason and Whitcomb 1965, Peck and Whitcomb 1970, Turnbull 1965, Whitcomb and Eason 1967) have not been able to prove or disprove that spiders regulate prey populations, or that they would be effective biological control agents .

The spider genus Latrodectus includes the widely known black widows, notorious because of the extreme potency of their neurotoxic venom (Wallece1942). The genus has a worldwide distribution and comprises 30 
currently recognized species, the phylogenetic relationships of which were previously unknown. Several members of the genus are synanthropic, and are increasingly being detected in new localities, an occurrence attributed to human mediated movement. In particular, the nearly cosmopolitan range of the brown widow, Latrodectus geometricus, is a suspected consequence of human transport. (Garb et al. 2004).

The brown widow spider Latrodectus geometricus is native to Africa; it is now found in many places around the world. In reproduce rapidly, making it one of the most abundant spiders in urban southern California. Habitat: Most species prefer open habitats with sparse vegetation and therefore are often found in semi-deserts. Only a few species live in woodlands. Latrodectus geometricus generally is found in close association with human habitats (Smithers 1944, Levy 1959, Lotz 1994, Levy 1998). Latrodectus geometricus is found at varying heights from the ground up to $1.5 \mathrm{~m}$. The web consists of a tube- to bell-shaped retreat spun of dry silk and the catching web containing the partially sticky catching threads (Szlep 1965, Lamoral 1968). Family Therididae is one of the most important families of spiders. It includes 2420 species of 121 genera distributed all over the world (Platnick, 2014). Mohafez 2000 mentioned that members of the family Philodromidae were found all over the year on vegetables, field crops and fruit trees in different locations at Sohag Governorate. (Sallam, et. al. 2015) use Theridion jordanense as predator of the larvae of Spodoptera littoralis which appears as the most dangerous pests distributing all over the fruit trees, field crops and vegetables plants.

In Egypt, spiders are found to be predators on insects and mites, which cause damages for many agricultural crops. The predatory habits of spiders are beneficial in the control of different pests. This study revealed that; there are little differences between males and females in the length of the developmental period up to maturity. Females maintain a stable cycle of one year, whereas the males show a change in the length of their developmental cycle, according to the phase from which they originate. The variance, which occurs among spiderlings, concerning the number of moults and the length of the different instars is discussed (Levy, 1970).

\section{MATERIALS AND METHODS}

An adult female Latrodectus geometricus was collected from the main campus of Al-Azhar University at Naser City, Cairo, near faculty of science. It was (3)found under a stone near a planted habitat in November 2013. It was kept in a small plastic vial and transferred to the laboratory. Identification was carried out by El-Hennawy (Egypt) and according to Levy (1998). The female spider was supplied with preys and kept in an incubator at $27 \pm 1^{\circ} \mathrm{C}$ and 70 $80 \%$ R.H. The female deposited 13 egg sacs between November 2013 and July 2014. Ten sacs hatched 596 spiderlings (the eggs of the last deposited three sacs did not hatch). At the tenth day after emergence of hatched 
spiderlings from the egg sacs they were individually reared in plastic vials of $1.5 \mathrm{~cm}$ diameter $\times 4 \mathrm{~cm}$ height, each spiderling alone, under the same laboratory conditions. Each spiderling was supplied with a known number of adults of the two-spotted red spider mite Tetranychus urticae Koch, as prey for the first and second instars, while the third and fourth instars were supplied with a known number of different stages of the common fruit fly Drosophila melanogaster Meigen,. then the fifth at the eighth instars and adults were supplied with a known number of different stages of larvae and adults of Spodoptera littoralis Boisd,. The hatched spiderlings were reared until reaching adulthood and transferred to larger vials $(3 \times 7 \mathrm{~cm})$ after third moult. Adults were reared to observe their mating behaviour and to study other aspects of the life cycle of the species.

\section{RESULTS AND DISCUSSION}

The genus Latrodectus is distributed widely throughout North America, with the greatest species diversity occurring in the southeastern United States Latrodectus geometricus is one of the most widely distributed species and found in cosmopolitan range, along the eastern seaboard, in Florida (Wallace 1942).

\section{Egg sac, eggs and incubation period}

Egg sac (Fig. 1): The egg sacs were often characteristic in appearance, brown, tough and parchment-like in L. tredecimguttatus, white, thin-walled and woolly in Latrodectus geometricus builds the most distinct cocoon, with a strikingly tufted envelope. The egg sacs are usually suspended inside the retreat. Latrodectus geometricus spins a dense sheltering web before oviposition. The greatest fecundity is found in L. geometricus with up to 30 cocoons and an average of 4096 eggs per female (Bouillon 1957 a). Females take care of the egg sac until hatching, but then neglect the hatchlings. The spiderlings bite a small hole and then emerge about 2-6 weeks after oviposition (Shulov 1940, Kaston 1970). Nevertheless, the time spent within the cocoon may vary greatly, as the spiderlings may stay several months inside the cocoon over the winter.

A considerable proportion of the eggs do not develop (10-15\%) after emergence the spiderlings stay near the cocoon for a few days until they disperse. During dispersal they are positively phototropic (Shulov 1940).

In this study the laid egg sacs of $L$. geometricus were circular in shape, slightly enlarged ( $8-10 \mathrm{~mm}$ in diameter relatively), and light yellow in color which changed to dark yellow just before hatching. The eggs were circular in shape and creamy in color after egg sac laying, changed to dark before hatching.

The incubation period was 41 days under laboratory conditions, $28^{\circ} \mathrm{C}$ \pm 2 and $60-70 \%$ R.H., after hatching the 61 spiderlings were reared. Most individuals died before adulthood. Only 24 individuals reached adult stage (16 males and 8 females). 
Table 1: Duration of different stages of $L$. geometricus when fed on different kinds of prey.

\begin{tabular}{|c|c|c|c|c|c|}
\hline \multirow{3}{*}{ DevelopmentalStage } & \multirow{3}{*}{ Prey } & \multicolumn{4}{|c|}{ Duration (days) } \\
\hline & & \multicolumn{2}{|c|}{ Male } & \multicolumn{2}{|c|}{ Female } \\
\hline & & Mean & S.D. & Mean & S.D. \\
\hline Incubation period of eggs & \multirow{5}{*}{$\begin{array}{c}\text { Tetranychus urticae, \& } \\
\text { Drosophila } \\
\text { melanogaster }\end{array}$} & 41 & 00 & 41 & 00 \\
\hline $1^{\text {st }}$ spiderling instar & & 17.25 & 2.04 & \begin{tabular}{|l|}
16.47 \\
\end{tabular} & 2.22 \\
\hline $2^{\text {nd }}$ spiderling instar & & 11.31 & 2.93 & 11.57 & 2.07 \\
\hline $3^{\text {rd }}$ spiderling instar & & 9.5 & 2.68 & 18.71 & 1.88 \\
\hline $4^{\text {th }}$ spiderling instar & & 13.06 & 1.98 & \begin{tabular}{|l|}
17.42 \\
\end{tabular} & 2.57 \\
\hline $5^{\text {th }}$ spiderling instar & \multirow{8}{*}{ Spodoptera littoralis } & --- & --- & 24.71 & 2.05 \\
\hline $6^{\text {th }}$ spiderling instar & & --- & --- & 19.00 & 2.16 \\
\hline $7^{\text {th }}$ spiderling instar & & --- & --- & 22.75 & 1.98 \\
\hline $8^{\text {th }}$ spiderling instar & & --- & ---- & 27.42 & 2.50 \\
\hline Total instars & & 50.53 & 3.27 & 157.57 & 2.69 \\
\hline Life cycle & & 91.15 & 3.27 & 198.57 & 2.96 \\
\hline Longevity & & 25.4 & 5.36 & 171 & 12.45 \\
\hline Lifespan & & 119 & 4.95 & 381.14 & 11.58 \\
\hline
\end{tabular}

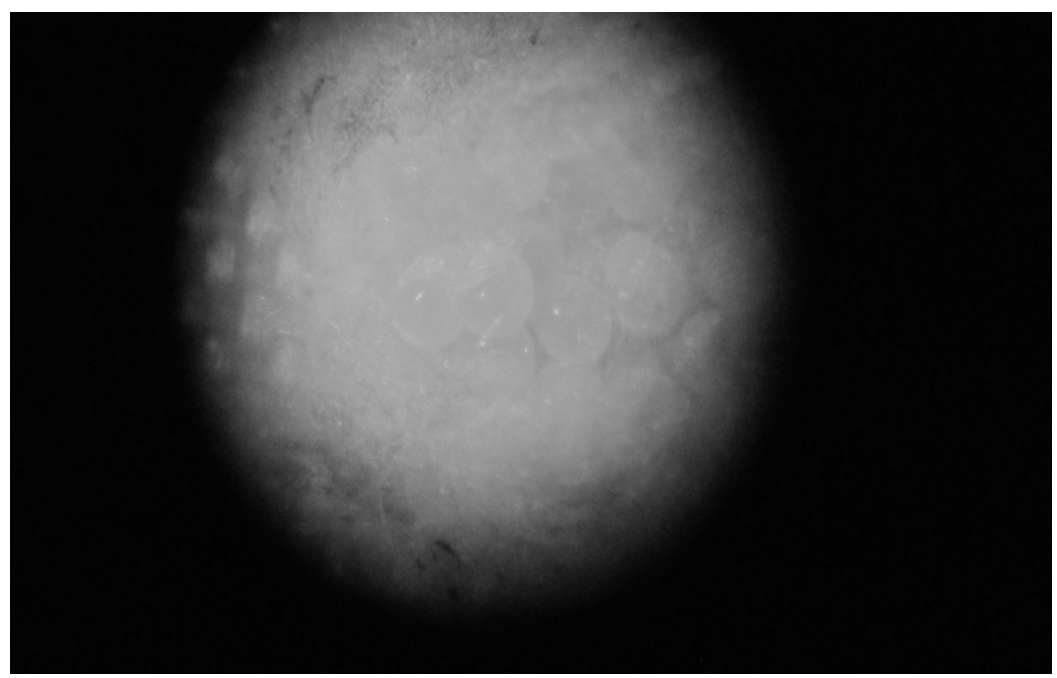

Fig. 1. Eggs inside egg sac of Latrodectus geometricus. 


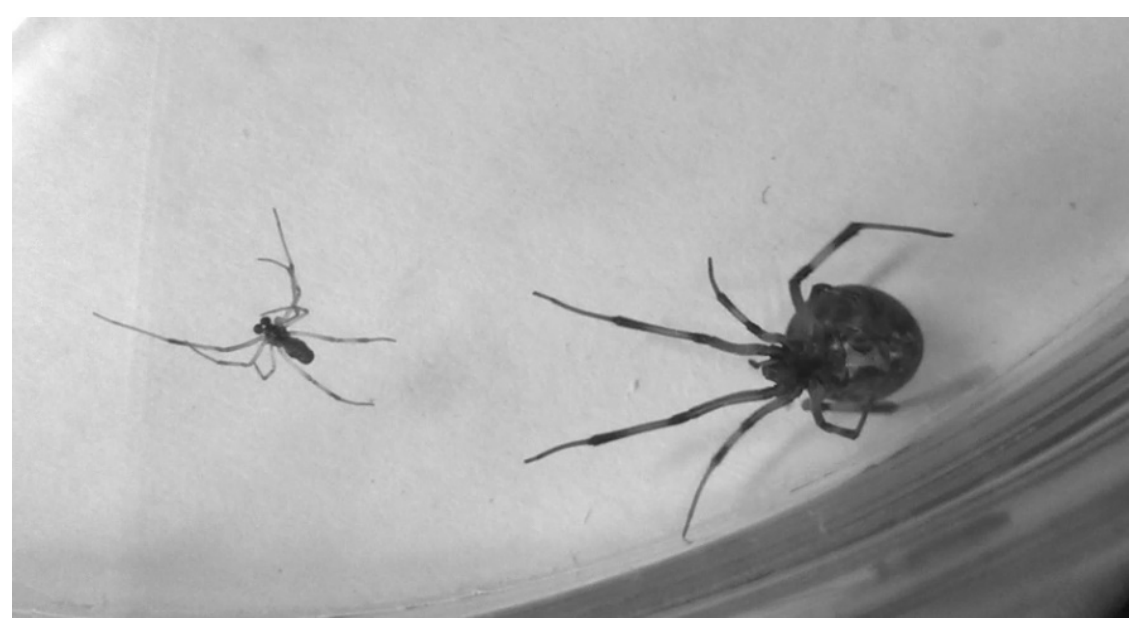

Fig. 2. Ventral view of male and female Latrodectus geometricus before mating.

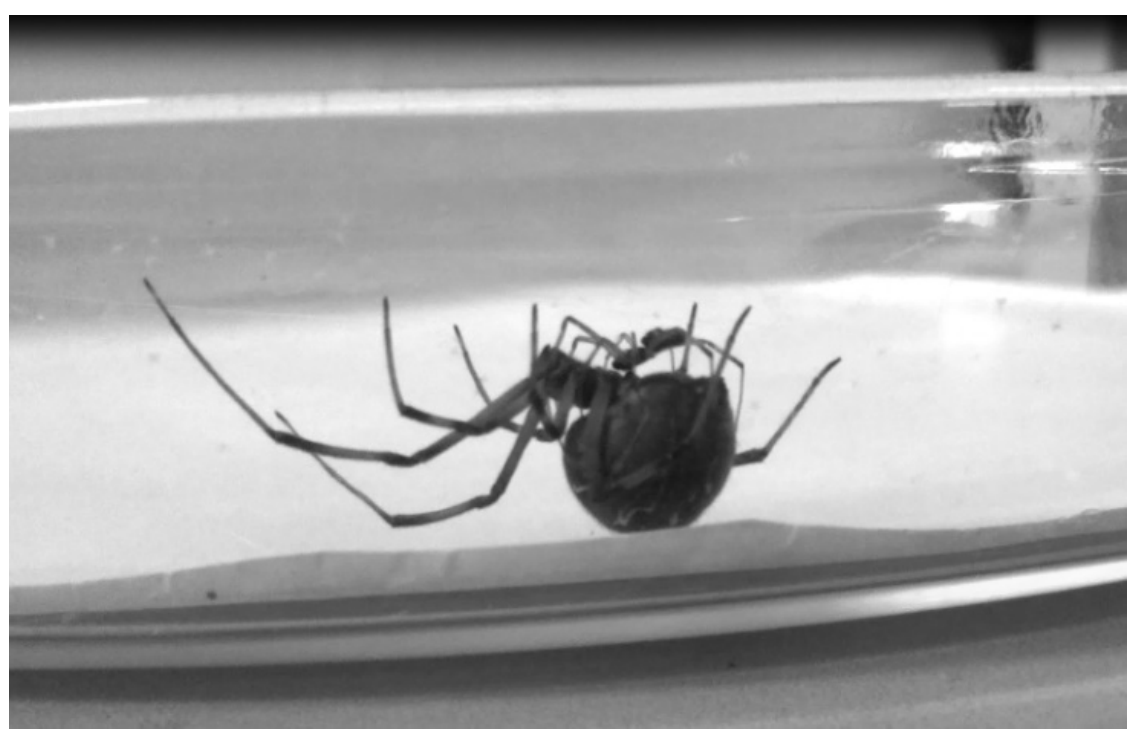

Fig. 3. Mating of a male (above) and female of Latrodectus geometricus in laboratory.

\section{Spiderlings:}

Spidere individuals were examined daily and the consumed prey individual swere replaced by fresh ones. Emerging females were allowed to mate and left alone until oviposition. The experiment begin with 61 
individuals, 24 of them reached to adult and the rest died before reaching maturity. The biological aspects and behaviour of different spiderlings of species were conducted.

\section{Adult :}

Total immature of Latrodectus geometricus reach to adult male and femal when both four and eight molted with fed on different prey species after (50.53 and 157.57) days for males and females respectively

The life cycle:

During rearing the 61 spiderlings of $L$. geometricus, 37 individuals died before reaching adult stage 24 individuals reached adult stage. The spiderlings passed through 6-8 instars for males and females during their development (Table 1). Sixteen percent of males became adult after four moults, while the eight percent of female after eight moulting. The longest duration was that of the first ${ }^{\text {th }}$ instar and eight instar with value ( $17.25-$ 27.42) day of male and female respectivly. The shortest instar was the third and secound instar with value (9. 5-11.57) day for both male and female showed in (Tabel-1).

Lifespan also differed according to sexes. Generally, adult female of $L$. geometricus lived longer than male when both sexes fed on the of different stages of $S$. littorales. Life span was also longer for females than that of males (about 119 and 381.14 days for male and female, respectively) shown in table (1). Foelix (1996) reported that most spiders of temperate regions live only one year; but some spiders live for two years. Generally, female spiders have longer life expectancy, and most males die shortly after mating.

Putman (1967) described the life cycle of Philodromus praetustris (Family: Philodromidae). Females of $P$. praetustris produced up to 12 egg sacs containing a -total of over 200 eggs in an insectary but the later eggs did not hatch. Fecundity in the orchards appeared to be considerably lower. Two species of ants were introduced as prey.

\section{Food consumption of $L$. geometricus under laboratory conditions:}

For rearing this species, several collected adult females were placed in a translucent plastic container cells $(5 \mathrm{~cm}$ in diameter and $10 \mathrm{~cm}$ length). Females were supplied with prey and kept in an Lab. at $27 \pm 1^{\circ} \mathrm{C}$ and $70-80 \%$ R.H. to deposit their eggs after mating. For individual rearing, the newly hatched spiderlings were kept solitarily in plastic containers under laboratory conditions. Each one was supplied with a known number of adults of the red spider Mite, T. urticae as prey for the first and second spiderling; while the third and fourth spiderling was supplied with a known number of a different stage of Dorosphila melanogastr and the fivith stage to untile lifespan was supplied the known nombers from different stages of larve Spodopetra lattorales) with taking into account their size Number of consumed prey species by different spiderling instars is showen that in Table (2). 
Table(2): Daily rate of food consumption to spiders $L$. geometricus in laboratory.

\begin{tabular}{|c|c|c|c|c|c|}
\hline \multirow{2}{*}{$\begin{array}{l}\text { Developmental } \\
\text { Stage }\end{array}$} & \multirow{2}{*}{ Preys } & \multicolumn{2}{|c|}{ Male } & \multicolumn{2}{|c|}{ Female } \\
\hline & & Mean & S.D. & Mean & S.D. \\
\hline $1^{\text {st }}$ spiderling instar & \multirow{4}{*}{$\begin{array}{c}\text { Titranycus urtica \& } \\
\text { Dorosophila } \\
\text { melanogaster }\end{array}$} & 4.75 & 0.61 & 5.00 & 0.74 \\
\hline \multirow{3}{*}{\begin{tabular}{|l}
$2^{\text {nd }}$ spiderling instar \\
$3^{\text {rd }}$ spiderling instar \\
$4^{\text {th }}$ spiderling instar \\
\end{tabular}} & & 6.00 & 1.48 & 6.50 & 1.11 \\
\hline & & 6.75 & 0.93 & 7.25 & 0.70 \\
\hline & & 7.31 & 0.70 & 8.00 & 0.92 \\
\hline $5^{\text {th }}$ spiderling instar & \multirow{4}{*}{$\begin{array}{c}\text { larvae of } \\
\text { Spodoptera littoralislis }\end{array}$} & --- & --- & 4.37 & 1.02 \\
\hline $6^{\text {th }}$ spiderling instar & & $-{ }_{--}$ & --- & 4.81 & 0.11 \\
\hline $7^{\text {th }}$ spiderling instar & & --- & -- & 3.68 & 0.60 \\
\hline $8^{\text {th }}$ spiderling instar & & --- & --- & 3.06 & 0.61 \\
\hline
\end{tabular}

The mean total number of consumed individuals was in the first star (81.93 \& 82.35) while the second instar was $(67.86$ \&75.20) when were feeding on red spiders mite ( $T$. urticae). The mean total number that consumed in the third and fourth instar was (64.12 \&135.64) and (95.46\&139.36) for both sex male and female, when feeding on Drosophila fly (D. melanogaster) from fifth moulting to (10) last feeding were on different stage from leaf worm cotton (S. littoralis) with value (108.48),(91.39),(83.72) and (83.90) respectively. However the adult individuals for male and female fed on different stage from $S$. littoralis. It is evident that the adult female $L$. geomtricus consumed prey much more than the male. This may be due to his smaller size and shorter longevity than female, these results agree with (Mohafez, 20oo),( Sallam,.et al.,2015) and (Ahmad, Naglaa.and Akram.s 2014 ).

\section{Acknowledgment}

I would like to thank Mr. Hisham El-Hennawy for his help in this work and identification of the spider species and kindly revised a draft of the manuscript.

\section{REFERENCES}

Ahmad, Naglaa, F. R. and Akram, S. Abd El- Maaboud. (2014). Biological Aspects of the Spider Theridion incanescens (Araneae: Theridiidae) Feeding on Tetranychus urticae and Ceratitis capitata with Notes on its Mating Behaviour Egypt. Acad. J. Biolog. Sci., 7(2): 9-14.

Bopillon, A. 1957. a. La fecondite chez l'araignee Latrodectus geometricus e. Koch. Studia Universitatis "Lovanium': Faculte des Sciences no. 1. Leopoldville (reprint) : 1-22.

Dondale, C . D . 1958 . Note on the population densities of spiders (Araneae) in Nova Scotia apple orchards. Canadian Entomol. $90: 11-113$.

Eason, R . and W . H . Whitcomb . 1965. Life history of the dotted wolf spider, Lycosa punctulata Hentz (Araneida:Lycosidae) . Arkansas Acad . Sci . Proc., $19: 11-20$. 
Foelix, R.F. (1996). Biology of Spiders. Second Edition. Oxford University Press and Georg ,Thieme ,Verlag, New York, Oxford. 330 pp.

Garb, J.E., Gonzalez, A. and Gillespie, R.G. (2004) The black widow spider genus Latrodectus (Araneae:Theridiidae): phylogeny, biogeography, and (11) invasion history. Molecular Phylogenetics and Evolution, 31: 1127-1142.

Gihan, M.E. Sallam. 1, Nahla A.I. Abd El-Azim1 \& Mohamm A.Mohafez2, 2015. A Study of some biological aspects of the spider Theridion jordanense Levy \& Amitai, 1982 (Araneae: Theridiidae) in Egypt. Egypt. Acad. J. Biolog. Sci., 8(1): 73-77 77

Huffaker, C . B . and P. S . Messenger. 1976. Theory and Practice of Biological Control . Academic Press, New York, 778 pp .

Kaston, B. 1970. Comparative biology of American black widow spiders. Transactions of the San Diego Society of Natural History16: 33-82.

Lamoral, B.H. 1968. On the nest and web structure of Latrodectus in South Africa, and some observations on body colouration of L. geometricus (Araneae: Theridiidae). Annals of the Natal Museum 20: 1-14.

Levy, H.W. 1959. The spider genus Latrodectus (Araneae, Theridiidae). Transactions of the American Microscopical Society 78: 7-43.

Levy, G. (1970): The life cycle of Thomisus onustus (Thomisidae: Araneae) and outlines for the classification of the life histories of spiders. J. of Zool

Levy, G. 1998. Fauna Palaestina. Arachnida Araneae f.: Theridiidae Israel Academy of Sciences and Humanities. Jerusalem. 227 pp.

Lotz, L.N. 1994. Revision of the genus Latrodectus (Araneae: Theridiidae) in Africa. Navorsinge van die Nasionale Museum Bloemfontein 10 (1) : 160.

Mohafez, M. A. M. (2000). Studies on true spiders in Sohag Governorate. M.Sc. Thesis, Fac. of Agric., Al- Azhar Univ., 115 p.

Peck, W . B . and W. H . Whitcomb . 1970. Studies on the biology of a spider

Characanthium inclusum (Hentz) . Univ . Arkansas Agr . Expt . Sta . Bull . 752, 1-76.

Platnick, N.I. 2014. The world spider catalog, version 14.5. American Museum ofNatural History, online at http://research.amnh.org/entomology/spiders/catalog/index.html

Putman, W . L . 1967 . Prevalence of spiders and importance as predators in Ontario peach orchards .Canadian Entomol., 99 :160-170 .

Robinson, M. H . and B . Robinson . 1970. Prey caught by a sample population of the spider Argiope argentata (Araneae :Araneidae) in Panama : A year's census data . Zool. J . Linn . Soc ., 49 :345-358 .

Shulov, A. 1940. On the biology of Latrodectus spiders in Palestine. Proceedings of the Linnean Society of London 152:309-328.

SMITHERS, R.H .N. 1944. Contributions to our knowledge of the genus Latrodectus (Araneae) in South Africa. Annals of the South African Museum 36: 263-313. 
Szlep, R. 1965. The web-spinning process and web-structure of Latrodectus tredecimguttatus, $L$. pallidus and $L$. revivensis. Proceedings of the Zoological Society of London 145: 75-89, pis 1-15.

Turnbull, A . L . 1965 . Effects of prey abundance on the development of the spider Agelenopsis potteri (Blackwell)(Araneae:Agelenidae) . Canadian Entomol ., $97: 141-147$.

Wallace,H.K.1942.A revision of the burrowing spiders of the genus Geolycosa (Araneae Lycosidae). Amer. Midland Natur., 27 :1-61 .

Whitcomb, W. H. 1973 . Natural populations of entomophagous arthropods and their effects on the agroecosystem. Proc . Mississippi Symp .Biocontrol,

Univ . Press Miss ., 150-169.

Whitcomb, W.H. and Eason, R. 1967. Life history and predatory importance of the striped lynx spider (Araneida: Oxyopidae). Arkansas Acad. Sci. Proc., 21: 54-58.

Whitcomb, W. H ., H. Exline and R. C. Hunter. 1963. Spiders of the Arkansas cotton field. Ann .Entomol. Soc. Amer., 56: 653-660.

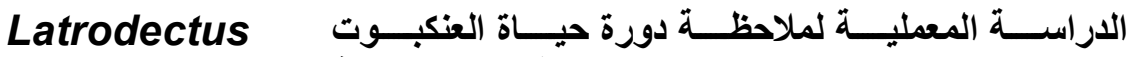
Theridiidae والأي ينتمي لعائلة geometricus Koch, 1841 محمد عبدالعال محمد محافظ كلية الزراعة - جالعال محمة مائهر -- القاهرة

اجريت هذه الدراسة البيولوجية على هذا النوع Latrodectus geometricus و التنابع لعائلة

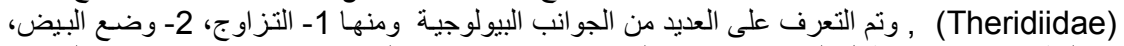

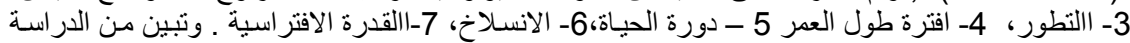

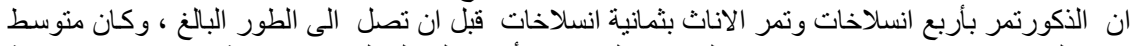

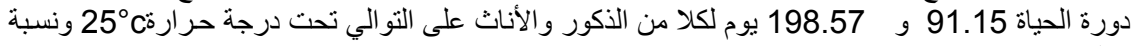

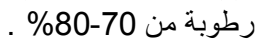

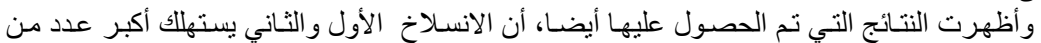

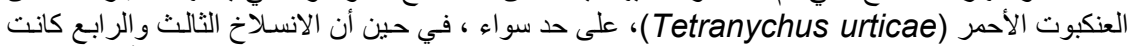

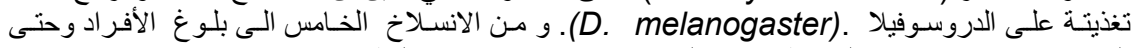

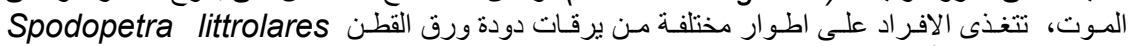
للأكور والإناث. وأوضحت الدراسة ان فترة العمر الكامل للعنكبوت كانت 119 للذكور و14.14 للاناناث

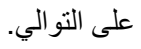

